\title{
The Effect of Moral Tax and Tax Compliance on Decision Making Through Gender Perspective: A Case Study of Religious Communities in Magetan District, East Java, Indonesia
}

\author{
Yunaita Rahmawati \\ IAIN Ponorogo, Jl. Puspita Jaya, Krajan, \\ Pintu, Kec. Jenangan, Kabupaten Ponorogo, \\ Jawa Timur 63492, Indonesia \\ Corresponding Author

\section{Arik Dwijayanto} \\ Sunan Giri Ponorogo, Jl. Batoro Katong No.32, \\ Ronowijayan, Kec. Siman, Kabupaten Ponorogo, \\ Jawa Timur 63411, Indonesia
}

DOI: https://doi.org/10.36941/ajis-2021-0168

\begin{abstract}
Religion-based communities have the potential to have tax morals and tax compliance and knowledge of taxes, then what if tax morals and compliance are reviewed from a gender perspective. The purpose of this study is to analyze the effect of tax morale and tax compliance on decision making through a gender perspective. The type of research approach used is quantitative correlational analysis using the Linear Regression test. Respondents amounted to 100 people who were members of the Yasinan group with the data collection method using a questionnaire. The results of the study indicate that 1) Tax morale and tax compliance have an influence on decision making with the correlation coefficient of the two independent variables being 0.564 and 0.495 . The amount of efficiency of tax moral determination and tax compliance on decision-making together is 0.368 . The regression line equation is $Y=0.360+0365 X_{1}+0.145 X_{2}$. 2) Gender does not affect the tax moral and tax compliance variables. 3) Women's tax morale is based on ethics and heart, while men's is based on logic and principles. Men dominate tax responsibilities in the family, however, in terms of financial arrangements for taxes and tax calculation, most of them are dominated by women.
\end{abstract}

Keywords: tax morale, tax compliance, gender

\section{Introduction}

Government has an authority to order citizens paying taxes on their income. As a matter of fact, frequent audits seem to be sufficiently not able to be committed (Allingham and Sandmo, 1972; Kleven et al., 2011). It is to be prevalent to have tax evasion compared to profit exposure (Andreoni et a., 1998). Some individuals did tax withholding by holding back tax morale (Luttmerr \& Singhal, 2014). It is agreed as an internal motivation to pay taxes (Torgler, 2002). It is an intrinsic motivation 
for taxpayers to comply with and pay taxes, so it should be the main focus of tax authority policies. Coupled with the Indonesian tax system which adopts a self-assessment system to be applied to individual taxpayers, namely a system that provides the flexibility to calculate, report, deposit and account for the tax obligations of individual taxpayers to the tax authorities. This self-assessment system is very prone to the possibility of lies, fraud and delays in reporting and deposits, so it requires a strong motivation from each taxpayer who comes from within himself to obey and obey the applicable tax laws (Firmantyas \& Imanda, 2016).

In ethical theory, morals are defined as individual values or principles for making right or wrong decisions. Departing from this logic, of course the decision to comply with taxes or not is also influenced by a value or principle held by the individual concerned. This value or principle when associated with religion can be called religiosity. Religiosity according to Johnson is seen as the extent to which individuals are committed to their religion and faith and apply their teachings so that individual attitudes and behaviors reflect this commitment (Utama, 2016). The compliance rate on tax in several degrees are along with the moral values which should be more on emphasizing the moral and social imperatives to share. The alignment on moral includes the feeling to have one another psychologically (Haidt, 2012), and also the loyal characters of the people (Green et al., 2004; Huddy, 2001). What people perceive as model both in morals and values to tax behavior becomes the alignment for individual identification for the evasion of its divergence by taxpayers (Haidt \& Graham, 2007). It turned into located that compliance turned into the identical in accurate returns as in clean returns and found greater compliance in the ones returns than or decrease returnswherein the latter did now no longer fluctuate in compliance. In contrast, each Doxey, Lawson, \& Stinson (2019) and Fochmann, Müller, \& Overesch (2018) located that compliance in accurate returns turned into similar to in better returns and additionally located greater compliance in the ones returns than in clean and decrease returns. Moreover, Doxeyetal. Found greater compliance in clean returns than in decrease returns, while in Fochmanetal.'s observes no distinction in compliance turned into located among those forms of returns. Thus, the most effective regular locating in those researches turned into that accurate returns yielded greater compliance than decrease returns; none of those researches supported a morality interpretation of compliance.

Tax compliance according to the Internal Revenue Service (IRS) can be defined through 33 variables, namely SPT submission compliance (filling compliance), payment compliance, and reporting compliance (Cahyonowati, 2011). It belongs to decisions related to income reports, fine and detection (Allingham \& Sandmo, 1972; Yitzhaki, 1974). In line with, it has a close relation of tax morale where tax evasion as a fear of being caught for moral reasons (Gordon, 1989). Institutional and socio-economic factors affect the intrinsic motivation to have prosaically behavior (OECD, 2019; Inglehart et al., 2014). Hashimzade et al. (2014, 2015, 2016) implement tax by job's role to set its compliance in varied community and faith for the audit among taxpayers. Personal/ individual roles are significant to improve the tax compliance through networks (Gamannossi degl'Innocenti \& Rablen, 2020). Spreading the information through the inner circle of family and colleagues are also seen to be effective on taxpayer's obligation (Frimmel et al., 2019; Alstadsater et al., 2019). It is found that some tax avoidances coming up in several ways such as; moving and contrasting in lower fractions company (Paetzold \& Winner, 2016). The job employment and performances determine the tax (Alwedyan, 2021). It has obvious difference among tax avoidance and evasion seen from its workers movement from one to another company (Bohne \& Nimczik ,2018; Hillman, 2019). The preventive actions have been done to reduce those practices by political interventions through regulations. The tax progression becomes debatable among the policymakers themselves to set up the regulations (Govori, 2019). It is then formed in a way of detections to comply (Rincke and Traxler, 2011). To add, Boning et al. (2018) stated that the tax authority has the impact in large scale directly as becoming the network for internal revenue. Chile, Pomeranz (2015) found that tax evasion uplifted to $12 \%$ after the implementation of tax authority on average. Similarly, Drago et al. (2020) found that the geographical characteristic needed to be monitored as the instrument for audit among taxpayers. It also relates to the efficiency on taxes (Harremi, 2013). 
Tax collection is not something that can be considered easy, in addition to the role of tax officers who must be active in collecting taxes on taxpayers, there must also be awareness of taxpayers to make tax payments. Taxpayer Compliance can be defined as compliance with respect to taxation in which the taxpayer must fulfill and implement all tax rights and obligations. Tax compliance will be closely related to the characteristics of a taxpayer. The Center for Tax Policy and Administration identifies factors that can influence taxpayer compliance behavior, including individual factors such as gender and education level. The term gender is associated with sex differences. That female taxpayers will be more obedient in paying taxes on conscientious grounds because they have a feeling of guilt if they do not pay taxes according to the amount they should, while male taxpayers emphasize more on fear of tax sanctions impose (Hendraswari, 2018).

Dupont (2004) describes and explores the encourage of items enhancements payment in Ontario. She reveals that 1) people with no children aren't different, 2) parents' willingness to pay is bigger than others, and 3) male dad and mom examine a few environmental items extra notably than females. However, the products that guys examine extra notably than ladies are strictly associated with sports activities (as an instance fishing reserves), and consequently the gender impact detected via way of means of Dupont can be in any sports events. Israel (2007) and Torgler and García-Valinas (2007) discover that females are extra inclined than male to allocate money into environmental issue, after managing for a sequence of variables, such as family income, schooling and marital status. Hsu et al. (2008) additionally discover a few gender impacts, studying the willingness to pay for better fuel taxes in British Columbia; however, of their paintings a few gender impacts seems only "occasionally". eight as already mentioned, the proof on gender impact in environmental economics research does now no longer attain a univocal conclusion. So, for instance, Solomon and Johnson (2009) do now no longer discover any impact on this sense, contributing to the environmental issue such as ethanol (a examine this is carefully associated with Hsu et al.).

While it's far crucial to evaluate the effect of religiosity and/or spiritual association on tax evasion, there's additionally a want to apprehend different moderating or contributing elements that would provide an explanation for this phenomenon. Nurunnabi (2018) argues that man or woman elements (including religiosity) similarly to regulatory and financial elements can provide an explanation for tax evasion in a few countries. In Bangladesh he exposed a dating among tax evasion, religious matter, and inflation that would provide an explanation for attitudes and behaviors into variance of tax. Assessing macro-degree financial elements, it is interesting, inspecting the interplay of religiosity and profits tiers greater completely developing the picture. Human beings are appeared to be assigned as individuals, and their profits tiers-by theory-must play insignificant roles of their moral options. It has a look at assessments this proposition.

\section{Methods/Material}

This study applied the analysis of Linear regression test as a part of correlational study. The coefficient of correlation as symbolized in ( $r$ ) explains how strength of two variables in the relationship. Its values ranging from -1 to 1 where o said as no relationship detected. In other words, it also can be said that the relationship tends to be stronger when it is closer to the value of -1 to 1 . There are some factors influencing the coefficient of the plot on the two variables in the scatterplot. The regression itself is defined as the association to uncover the variables. It is very essential to meet the assumptions before conducting the regression by understanding a proper interpretation of its equation.

The sample of this study was the Yasinan group of Belotan Village consisting of 100 people divided into 30 men and 70 women who all live around the Miftahurrosyid Mosque, Belotan Village, Bendo District, Magetan Regency, East Java. This Yasinan group was formed in 2008 with the main activity being a traveling organization that takes turns in the house of group members every 1 month and is carried out separately, both in terms of management and implementation of activities between male and female groups. The male member of the group is a family head in each household who has a 
job, either permanent or irregular or uncertain. Meanwhile, women who are members of the Yasinan group are housewives who also all have jobs as civil servants, retirees, farmers, traders, tailors, laborers, and housewives. All women members of the yasinan group also play a role in finding additional income to help their husbands meet family needs, including fulfilling tax obligations, both income tax, land and building tax, motor vehicle tax, and other taxes (Respondent 1 ).

This study prioritizes members of the Belotan Village yasinan group as respondents because in the opinion of the researcher, members of the yasinan group have the potential to have good tax morale and tax compliance in terms of religiosity in terms of types of religious activity-based groups, in addition to having knowledge about taxes and providing good responses to be used respondents in the study. So, it is hoped that this research can be carried out on time and obtain valid and reliable data.

According to Mr. Suyitno, TNI AU, 50 years old, paying legal taxes must be fulfilled because it is needed by the state to manage government affairs and the Indonesian nation so that it must be paid on time (Respondent 9).

According to Mr. Sukarno, a retired police officer, 62 years old, motor vehicle tax must be paid on time, while income tax and land and building tax are sometimes not on time because sometimes, they forget and tax officials never write to remind them (Respondent 22).

Mr. Mali, a businessman, 48 years old, said that taxes are very burdensome for home-based entrepreneurs like him, especially VAT. And the imposition of tax penalties is increasingly burdensome so that some people pay taxes for fear of tax penalties not because they voluntarily pay taxes (Respondent 24).

In terms of tax compliance, based on the results of an interview with Mrs. Sumijem, a retiree, 68 years old, said that the role of a mother is needed, among others, to remind, help pay, to help pay taxes from her own income or from other sources that she cultivates (Respondent, 28).

In contrast to Mrs. Martini, a farm worker, 50 years old, said that tax matters were her husband's obligation, so it did not matter whether the tax had been paid or not and if he was subject to tax penalties it was not his concern (Respondent 30).

Meanwhile, according to Mrs. Sudarmi, a trader, 50 years old, said that she objected to the tax burden because she felt that the money, she earned was the result of her own hard work which she was entitled to enjoy (Respondent 35).

Based on the description of the theory and the results of the interview above, it shows that there is a difference between the theory and the facts in the male and female Yasinan group of Belotan Village. Therefore, this study takes the title "The Moral Influence of Taxes and Tax Compliance on Decision Making through a Gender Perspective (Case Study in the Belotan Village Yasinan Group)".

\section{Results and Discussions}

\subsection{Predisposing Factors of the Respondents}

Tax morale can be defined as the intrinsic motivation to comply with and pay taxes so as to contribute voluntarily to the provision of public goods. The moral of taxation is a key determinant that can explain why people are honest in tax matters. Meanwhile, tax compliance can be stated as a condition of taxpayer (WP) fulfills for the payments to meet taxation rights. Tax compliance theory refers to the Minister of Finance Decree No. 544 / KMK.04 / 200o, for all types of taxes in the last two years within the last 10 years subjected to an audit, correction of the last examination for each type of tax owed is not more than $5 \%$ (Cahyonowati, 2011).

The main key of tax compliance is the moral imperative. It is found that there was intrinsic motivation among the tax payers by previewing their income through IRS. They do not see the action as an obligatory activity but it tends to be a good thing to do implicated to others. It was properly right to give effect on social life (Durkheim, 1961, 1965; Goffman, 1959; Weber, 1930): it covers attitude, manner, behavior, morality. Tax is seen as to be ultimately voluntary action as the stem for 
moral judgment and attitude. In the U.S. perspective, paying tax is a fundamental basis of moral matter; it is not about right or wrong, unacceptable or acceptable. It is a responsibility for the people and community not only a matter of morality or behavior reflection (Ariely, 2012; Williamson, 2017).

While the above studies have been indicative, different much less recognized reasserts of fatwas (non-secular edicts) on the subject of tax evasion had been now no longer covered with inside the dialogue of tax evasion. There are many such edicts that argue that it might in no way be appropriate to prevent taxes in an Islamic country. Ibn Uthaimeen (2020, n.d.) stated that Muslim need to follow the authorities even supposing for illegal tax. Likewise, numerous Egyptian students from the distinguished Azhar non secular college stated that tax evasion is illegal and that human beings should pay what's requested of them thru the tax laws. Dar-al-Iftaa (2014) notes that it may want to thoroughly represents very non secular Muslims who generally tend to trust above. They constitute a part of the non-secular network who could now no longer question authority. Whether that is certainly continuously the case wishes to be supported through destiny studies.

Criteria for Compliant Taxpayers, The Minister of Finance of the Republic of Indonesia issued the regulations listed in No.74 / PMK.03 / 2012 Article 2 as a requirement to enter into the compliance taxpayer criteria: 1 . Be on time in submitting Tax Returns 2. Postponing the tax to arrear for any payments of installments 3. Public appraisal or audit from the public for open and qualified opinion in consecutive years 4 . Never been convicted for committing an act tax penalty based on judicial decisions which have permanent legal force within the last 5 (five) years.

In terms of gender, the Center for Tax Policy and Administration in 2004 identified factors that can influence taxpayer compliance behavior, including individual factors such as gender. This is also supported by research according to Ganda Frisno Rasaribu and Christine Tjen in 2016 which mentions demographic factors towards tax compliance in Indonesia, including gender. Gender is an interesting factor to research regarding tax compliance. Several studies have shown that female taxpayers will obey to pay taxes on conscientious grounds or have a feeling of guilt if they do not pay taxes according to the amount they should, while male taxpayers emphasize fear of sanctions being imposed (Kakunsi et al, 2017).

The theory of decision making in this study is associated with decision making that is based on ethical action. It covers two perspectives regarding the factors that impact to the unethical actions by an individual. First, the view that argues that unethical actions or decisions tend to be influenced by the moral character of the individual. Second, environment gives the influence in unethical actions, for example the company's reward and punishment system, the organizational climate and the socialization of professional ethics by the organization where the individual works. Individual characteristic factors that influence decision making include the stages of moral development, gender, locus of control, and Machiavellian character. Several previous studies concluded that there are several factors that influence an ethical decision-making process (Tjongari, 2014). That tax compliance is related to ethical or unethical if an individual taxpayer is tax compliant or noncompliant.

\subsection{The Moral Influence of Taxes on Decision Making ( $\left.\mathrm{HI}_{\mathrm{I}}\right)$}

The results of testing the effect of tax morale on decision making using SPSS software found that value the significance is 0.00 which means that Ho is rejected and Ha is accepted, or in other words, there is a significant effect of the tax moral variable on the decision-making variable. While the magnitude of this influence can be seen from the correlation coefficient of 0.564 , which means that the greater a person's tax morale, the more likely he is to make decisions, especially those related to taxes. The Effect of Tax Compliance on Decision Making $\left(\mathrm{H}_{2}\right)$ The significance value of the results of the correlation test between the variable tax compliance and decision making is o.ooo Ha accept and Ho reject, which means that there is an influence between the two variables. While the correlation coefficient is 0.495 . 


\subsection{The Effect of Gender on Tax Moral and Tax Compliance}

Based on the results of the correlation test, it is proven that there is no significant influence between gender and tax morale seen from the significance value of 0.629. This explains that women and men have the opportunity to have the same tax morale, it could be that women have better tax morals than men or vice versa. The significance value of 0.365 from the results of the correlation test between the gender variable and the tax compliance variable proves that Ho is accepted and Ha is rejected, which means that there is no significant effect between the two. This also means that men and women have relatively equal tax compliance or in other words women can have greater tax compliance than men and vice versa men can have greater tax compliance than women. So, it can be concluded that a person's tax compliance does not depend on the gender of men and women.

\subsection{The Effect of Tax Moral and Tax Compliance on Decision Making}

To see how the influence of tax moral and tax compliance variables on decision making is to compare $\mathrm{F}$ count with $\mathrm{F}$ table and see the significance value.

Table 1: ANOVA a

\begin{tabular}{|c|c|c|c|}
\hline Df & Mean Square & F & Sig. \\
\hline 2 & 114.199 & 27.087 &. ooob \\
93 & 4.216 & & \\
95 & & & \\
\hline
\end{tabular}

a. Dependent Variable: Decision Making

b. Predictors: (Constant), Tax Compliance, Tax Moral

Based on the test results, it is known that the $\mathrm{F}$ count is 27,087 , where the number is greater than the F table of 3.09 and with a significance value of 0.000 which is less than 0.05 , indicating that Ho is rejected and Ha is accepted, which means that there is a significant effect of the two tax moral variables. and joint tax compliance on decision making.

Table 2: Model Summary

\begin{tabular}{|c|c|c|c|c|}
\hline Model & $\mathrm{R}$ & R Square & Adjusted R Square & Std. Error of the Estimate \\
\hline 1 & $.607 \mathrm{a}$ & .368 & .355 & 2.053 \\
\hline
\end{tabular}

\section{a. Predictors: (Constant), Tax Compliance, Tax Moral}

The coefficient of determination of the influence of the tax moral and tax compliance variables on decision making is 0.368 which is obtained from the $\mathrm{R} 2$ value. Based on the coefficient of determination, it can be concluded that $36.8 \%$ of the tax decision-making variables are influenced by the tax moral and tax compliance variables collectively, the remaining $63.2 \%$ is influenced by other variables.

Table 3: Coefficient a

\begin{tabular}{|c|c|c|c|c|c|}
\hline \multirow[t]{2}{*}{ Model } & \multicolumn{2}{|c|}{ Unstandardized Coefficients } & \multirow{2}{*}{$\begin{array}{c}\text { Standardized Coefficients } \\
\text { Beta } \\
\end{array}$} & \multirow[t]{2}{*}{$\mathrm{t}$} & \multirow[t]{2}{*}{ Sig. } \\
\hline & $\mathrm{B}$ & Std. Error & & & \\
\hline (Constant) & .360 & 1.636 & & .220 & .826 \\
\hline Tax Moral & .365 & .086 & .419 & 4.263 & .000 \\
\hline Tax Compliance, & .145 & .054 & .266 & 2.701 & .008 \\
\hline
\end{tabular}




\section{b. Dependent Variable: Decision Making}

The regression line equation of the tax moral regression model and tax compliance on decision making is as follows: $\mathrm{Y}=0.360+0365 \mathrm{X}_{1}+0.145 \mathrm{X}_{2}$.

\subsection{Description of Tax Morals, Tax Compliance, and Decision Making}

Through a Gender Perspective To find out more about the moral taxation of the Belotan Village Yasinan group from a gender perspective, the following table is compiled based on the presentation of men and women in answering each question in the questionnaire.

Table 4: Percentage of Responses to Moral Taxes

\begin{tabular}{|c|c|c|c|c|c|c|c|}
\hline No & Questions & & SDA & DA & $\mathrm{N}$ & A & SA \\
\hline \multicolumn{8}{|c|}{ Ethics violations and guilt } \\
\hline \multirow{2}{*}{1} & \multirow{2}{*}{$\begin{array}{l}\text { I feel it violates ethics if I don't meet my tax } \\
\text { obligations }\end{array}$} & $\mathrm{F}$ & $\mathrm{o} \%$ & $10.8 \%$ & $15.4 \%$ & $47.7 \%$ & $26.2 \%$ \\
\hline & & $\mathrm{M}$ & $3.2 \%$ & $9.7 \%$ & $32.3 \%$ & $38.7 \%$ & $5 \%$ \\
\hline \multirow{2}{*}{2} & \multirow[t]{2}{*}{ I feel guilty if I don't meet my tax obligations } & $\mathrm{F}$ & $\mathrm{o} \%$ & $7.7 \%$ & $13.8 \%$ & $55.4 \%$ & $23.1 \%$ \\
\hline & & $\mathrm{M}$ & $\mathrm{o} \%$ & $3.2 \%$ & $29 \%$ & $48.4 \%$ & $19.4 \%$ \\
\hline \multicolumn{8}{|c|}{ Principles of life and compliance with regulations } \\
\hline \multirow[b]{2}{*}{3} & \multirow{2}{*}{$\begin{array}{l}\text { I violate the principle of life if I do not fulfill my tax } \\
\text { obligations. }\end{array}$} & $\mathrm{F}$ & o\% & $9.2 \%$ & $40 \%$ & $38.5 \%$ & $12.3 \%$ \\
\hline & & $\mathrm{M}$ & $\mathrm{o} \%$ & $3.2 \%$ & $29 \%$ & $38.7 \%$ & $29 \%$ \\
\hline \multirow[b]{2}{*}{4} & \multirow{2}{*}{$\begin{array}{l}\text { I violate tax procedures if I don't meet my tax } \\
\text { obligations }\end{array}$} & $\mathrm{F}$ & $\mathrm{o} \%$ & $3.1 \%$ & $33.8 \%$ & $49.2 \%$ & $13.8 \%$ \\
\hline & & $\mathrm{M}$ & $\mathrm{o} \%$ & $3.2 \%$ & $22.6 \%$ & $35.5 \%$ & $38.7 \%$ \\
\hline
\end{tabular}

There are interesting things that we can find based on the table above. The first and second items in the tax moral variable are related to ethics and feelings of guilt, while the third and fourth items represent sub-indicators of life principles and regulatory obligations. After further examination, the percentage of respondents 'answers in the first and second items, it can be seen that female respondents dominate the answers with a maximum score or a score of 5 which represents the answers strongly agree, namely with a percentage of $26.2 \%$ and $23.1 \%$ while the percentage of respondents' answers with male gender is $5 \%$ and $19.4 \%$.

Different from the first and second items, the percentage of male respondents 'answers to the third and fourth points was more dominant with a percentage of $29 \%$ and $38.7 \%$, while the percentage of respondents' answers with female gender was $12.3 \%$ and $13.8 \%$.

The conclusion from the two findings above is that both men and women have the opportunity to have good tax morals even though the basis and perspective of tax morals owned by men are different from women. If the tax morale of women is more based on feelings or conscience, it can be seen from the percentage of women's answers that dominate the sub-indicators of ethics and feelings of guilt, then male respondents have tax morals based on logic and reason, as evidenced by the percentage of answers that dominate sub indicator 2 concerning principles of life and obligation of rules.

\subsection{Tax Compliance}

There are eight statement items that represent the tax compliance variable which consists of 3 indicators, namely the tax registration indicator, tax calculation and reporting, and the tax payment indicator. 
Table 5: of Percentage of Tax Compliance Respondents' Answers.

\begin{tabular}{|c|c|c|c|c|c|c|c|}
\hline No & Question & & SDA & DA & $\mathrm{N}$ & A & SA \\
\hline \multicolumn{8}{|c|}{ Taxpayer Registration } \\
\hline \multirow{2}{*}{1} & \multirow[t]{2}{*}{ I registered as a Taxpayer on my own accord. } & $\mathrm{F}$ & $3.1 \%$ & $6.2 \%$ & $15.4 \%$ & $58.5 \%$ & $16.9 \%$ \\
\hline & & $\mathrm{M}$ & $\mathrm{o} \%$ & $3.2 \%$ & $19.4 \%$ & $48.4 \%$ & $29 \%$ \\
\hline \multirow{2}{*}{2} & \multirow{2}{*}{$\begin{array}{l}\text { I filled out an SPT (Annual Tax Return) in accordance with } \\
\text { statutory provisions }\end{array}$} & $\mathrm{F}$ & o\% & $\mathrm{o} \%$ & $16.9 \%$ & $55.4 \%$ & $27.7 \%$ \\
\hline & & $\mathrm{M}$ & o\% & $\mathrm{o} \%$ & $16.1 \%$ & $48.4 \%$ & $35 \cdot 5 \%$ \\
\hline \multicolumn{8}{|c|}{ Tax calculation and payment } \\
\hline \multirow[b]{2}{*}{3} & \multirow[t]{2}{*}{ I submit the SPT before the deadline for submitting the SPT. } & $\mathrm{F}$ & $\mathrm{o} \%$ & $3.1 \%$ & $13.8 \%$ & $58.5 \%$ & $24.6 \%$ \\
\hline & & $\mathrm{M}$ & $\mathrm{o} \%$ & $\mathrm{o} \%$ & $19.4 \%$ & $45.2 \%$ & $35 \cdot 5 \%$ \\
\hline \multirow[b]{2}{*}{4} & \multirow[t]{2}{*}{ I calculate the tax owed correctly and pay it on time. } & $\mathrm{F}$ & $\mathrm{o} \%$ & $1.5 \%$ & $20 \%$ & $55.4 \%$ & $23.1 \%$ \\
\hline & & $\mathrm{M}$ & $\mathrm{O} \%$ & $\mathrm{o} \%$ & $12.9 \%$ & $71 \%$ & $16.1 \%$ \\
\hline \multirow{3}{*}{5} & \multirow[t]{3}{*}{ I paid the tax shortfall before the inspection was carried out } & $\mathrm{F}$ & $\mathrm{o} \%$ & $3.1 \%$ & $21.5 \%$ & $53.8 \%$ & $21.5 \%$ \\
\hline & & $\mathrm{M}$ & $\mathrm{o} \%$ & $3.2 \%$ & $19.4 \%$ & $54.8 \%$ & $22.6 \%$ \\
\hline & & $\mathrm{M}$ & $3.2 \%$ & $9.7 \%$ & $29 \%$ & $41.9 \%$ & $16.1 \%$ \\
\hline \multicolumn{8}{|c|}{ Bookkeeping and reporting of SPT } \\
\hline \multirow{2}{*}{7} & \multirow{2}{*}{ I do books or tax records. } & $\mathrm{F}$ & $\mathrm{O} \%$ & $7.7 \%$ & $23.1 \%$ & $53.8 \%$ & $15.4 \%$ \\
\hline & & $\mathrm{M}$ & $3.2 \%$ & $\mathrm{o} \%$ & $16.1 \%$ & $58.1 \%$ & $22.6 \%$ \\
\hline \multirow{2}{*}{8} & \multirow{2}{*}{$\begin{array}{l}\text { Tax officers collect taxes in accordance with applicable laws and } \\
\text { regulations. }\end{array}$} & $\mathrm{F}$ & $\mathrm{o} \%$ & $\mathrm{o} \%$ & $23.1 \%$ & $64.6 \%$ & $12.3 \%$ \\
\hline & & $\mathrm{M}$ & $\mathrm{O} \%$ & $\mathrm{o} \%$ & $19.4 \%$ & $45.2 \%$ & $35 \cdot 5 \%$ \\
\hline \multirow[b]{2}{*}{9} & \multirow{2}{*}{ I have submitted the SPT according to taxation requirements } & $\mathrm{F}$ & $\mathrm{o} \%$ & $6.2 \%$ & $15.4 \%$ & $60 \%$ & $18.5 \%$ \\
\hline & & $\mathrm{M}$ & $\mathrm{o} \%$ & $\mathrm{o} \%$ & $19.4 \%$ & $58.1 \%$ & $22.6 \%$ \\
\hline
\end{tabular}

In contrast to the tax morale variable, in the tax compliance variable the percentage of answers of male respondents and female respondents is relatively the same which also means that no percentage of answers dominates one another. The conclusion is that both men and women have the same opportunity to have the same tax compliance. One reason for the absence of this difference is that if the tax morale is a fundamental difference regarding the respective perspectives on taxes, tax compliance is more related to the application and application of the tax morals that are owned. In addition, the tax compliance variable is more technical in tax registration, tax reporting, and tax payment.

\subsection{Making Tax Paying Decisions}

The decision-making variable in tax consists of 3 statements relating to the responsibility for calculating and paying taxes.

Table 6: Percentage of Answers for Decision Making Respondents

\begin{tabular}{|c|c|c|c|c|c|c|c|}
\hline No & Question & & Never & Seldom & Sometimes & Frequently & Always \\
\hline \multirow[b]{2}{*}{1} & \multirow{2}{*}{$\begin{array}{l}\text { I am fully responsible for paying } \\
\text { taxes }\end{array}$} & $\mathrm{F}$ & $1.5 \%$ & $4.6 \%$ & $32.3 \%$ & $43.1 \%$ & $18.5 \%$ \\
\hline & & $\mathrm{M}$ & $\mathrm{o} \%$ & $12.9 \%$ & $29 \%$ & $22.6 \%$ & $35 \cdot 5 \%$ \\
\hline \multirow{2}{*}{2} & \multirow[t]{2}{*}{ I set aside family finances for taxes } & $\mathrm{F}$ & $\mathrm{o} \%$ & $9.2 \%$ & $35.4 \%$ & $32.3 \%$ & $23.1 \%$ \\
\hline & & $\mathrm{F}$ & $\mathrm{O} \%$ & $25.8 \%$ & $35 \cdot 5 \%$ & $29 \%$ & $9.7 \%$ \\
\hline \multirow[b]{2}{*}{3} & \multirow{2}{*}{$\begin{array}{l}\text { I calculate the tax that must be paid } \\
\text { in the family }\end{array}$} & $\mathrm{F}$ & $1.5 \%$ & $4.6 \%$ & $15.4 \%$ & $44.6 \%$ & $33.8 \%$ \\
\hline & & $\mathrm{M}$ & $\mathrm{o} \%$ & $22.6 \%$ & $41.9 \%$ & $25.8 \%$ & $9.7 \%$ \\
\hline
\end{tabular}

In this decision-making variable, there are several things that we can find. The first point concerns individuals who have full responsibility for paying taxes. Based on the respondents' answers, it was found that although the tax responsibility was dominated by male respondents, namely as much as $35.5 \%$, there were also many women who took full responsibility for this responsibility as much as $18.5 \%$, while the rest shared their responsibilities with other family members.

In the second and third points relating to tax regulation and calculation, it is found that women 
dominate this matter more. This is consistent with several studies which state that in a family most of the people in charge of finances are women.

\section{Conclusions and Recommendations}

Tax morale and tax compliance have an influence on decision making, both individually and collectively. The correlation coefficient values of the two independent variables are 0.564 and 0.495 . The amount of efficiency of tax moral determination and tax compliance on decision making together is 0.368 which means that $36.8 \%$ of decision making is influenced by tax morale and tax compliance. The regression line equation is $\mathrm{Y}=0.360+0365 \mathrm{X}_{1}+0.145 \mathrm{X}_{2}$.

Gender does not affect the tax moral and tax compliance variables. Both women and men have the same opportunity to have good tax morale and tax compliance.

Based on the answers of respondents who have been presented by women and men, both have good tax morals, it's just that women's tax morals are based on ethics and heart, while men's tax morals are based on logic and principles. For the tax compliance variable there is no significant difference, both men and women have the opportunity to have good tax compliance. As for the decision-making variable, men fully dominate the taxation responsibility, although not a few women also carry this responsibility, however, in terms of financial arrangements for taxes and tax calculation, it turns out that many are dominated by women.

\section{References}

Allingham, M., \& Sandmo, A. (1972). Income tax evasion: a theoretical analysis. J. Publ. Econ. 1 (3-4), 323-338. https://doi.org/10.1016/o047-2727(72)90010-2

Alstadsater, A., Kopczuk, W., \& Telle, K. (2019). Social networks and tax avoidance: evidence from a well-defined Norwegian tax shelter. Int. Tax Publ. Finance 26 (6) 1291-1328. https://doi.org/10.1007/s10797-019-09568-3

Alwedyan, M. A. (2021). The impact of training session on job performance of employees at income tax and sales department in Irbid Province. Academic Journal of Interdisciplinary Studies, 10 (1), 22-33. https://doi.org/10.36941/ajis-2021-0003

Andreoni, J., Erard, B., \& Feinstein, J. (1998). Tax compliance. Journal of Economic Literature, 36, 818-86o.

Ariely, D. (2012). The Honest Truth about Dishonesty. HarperCollins, New York, NY.

Bohne, A., \& Nimczik, J.S. (2018). Information Frictions and Learning Dynamics: Evidence from Tax Avoidance in Ecuador. IZA Discussion Paper No. 11536. Bonn.

Boning, W., Guyton, J., Hodge, R., Slemrod, J., \& Troiano, U. (2018). Heard it through the Grapevine: Direct and Network Effects of a Tax Enforcement Field Experiment. NBER Working Paper No. 24305. Cambridge MA. https://doi.org/10.3386/w24305

Cahyonowati, N. (2011). Model Moral Dan Kepatuhan Perpajakan. JAAI, 15, 161-177.

Dar-al-Iftaa. (2014). Tax evasion. Dar al-Iftaa Al-Missriyyah. Available at https://www.daralifta.org/AR/ViewFatwa.aspx?ID=12807\&LangID=1 (accessed on 1 July 2020).

Doxey, M., Lawson, J., Shane S. S. (2019). The effects of prefilled tax returns on taxpayer compliance. Unpublished manuscript.

Drago, F., Mengel, F., \& Traxler, C. (2020). Compliance behaviour in networks: evidence from a field experiment. Am. Econ. J. Appl. Econ. 12 (2), 96-133. https://doi.org/10.1257/app.2017069o

Dupont, D.P. (2004). Do children Matter? An examination of gender differences in environmental valuation. Ecol. Econ. 49, 273-286.

Durkheim, E. (1961). Moral Education: A Study in the Theory and Application of the Sociology of Education. Free Press, New York.

Durkheim, E. (1965). The Elementary Forms of Religious Life. Free Press

Firmantyas, P. P., \& Imanda. (2016). Moral Pajak: Sebuah Opsi Peningkatan Kepatuhan Pajak Masyarakat Muslim.” IAIN Surakarta.

Fochmann, M., Müller, N., Overesch, M. (2018). Less cheating? The effects of prefilled forms on compliance behavior. Arbeitskreis Quantative Steuerlehre (arqus), Berlin Arqus Discussion Paper, No. 227.

Frimmel, W., Halla, M., \& Paetzold, J. (2019). The intergenerational causal effect of tax evasion: evidence from the commuter tax allowance in Austria. J. Eur. Econ. Assoc. 17 (6), 1843-188o. https://doi.org/10.1093/jeea/jvyo33 
Gamannossi degl'Innocenti, D., \& Rablen, M. (2020). Tax evasion on a social network. J. Econ. Behav. Organ. 169 (C), 79-91. https://doi.org/10.1016/j.jebo.2019.11.001

Goffman, E. (1959). The Presentation of Self in Everyday Life. Doubleday, Garden City, NY.

Gordon, J. (1989). Individual morality and reputation costs as deterrents to tax evasion. Eur. Econ. Rev. 33 (4), 797-805. https://doi.org/10.1016/oo14-2921(89)90026-3

Govori, F. (2019). Personal tax progression in Kosovo. Academic Journal of Interdisciplinary Studies, 8 (3), $79-89$. https://doi.org/10.36941/ajis-2019-0007

Green, D., Bradley, P., \& Schickler, E. (2004). Partisan Hearts and Minds: Political Parties and the Social Identity of Voters. Yale University Press, New Haven, CT.

Haidt, J. (2012). The Righteous Mind: Why Good People Are Divided by Politics and Religion. Pantheon Books.

Haidt, J., \& Graham, J. (2007). When morality opposes justice: conservatives have moral intuitions that liberals may not recognize. Soc. Justice Res. 20, 98-116. https://doi.org/10.1007/s11211-007-0034-z

Harremi, M. (2013). The flat tax and efficiency of fiscal system. Academic Journal of Interdisciplinary Studies, 2 (8), 446-450. https://doi.org/10.5901/ajis.2013.v2n8p446

Hashimzade, N., Myles, G., \& Rablen, M. (2016). Predictive analytics and the targeting of audits. J. Econ. Behav. Organ. 124, 130-145. https://doi.org/10.1016/j.jebo.2015.11.009

Hashimzade, N., Myles, G., Page, F., \& Rablen, M. (2014). Social networks and occupational choice: the endogenous formation of attitudes and beliefs about tax compliance. J. Econ. Psychol. 40, 134-146. https://doi.org/10.1016/j.joep.2012.09.002

Hashimzade, N., Myles, G., Page, F., \& Rablen, M. (2015). The use of agent-based modelling to investigate tax compliance. Econ. Govern. 16 (2), 143-164. https://doi.org/10.1007/s10101-014-0151-8

Hendraswari, A. D. (2018). Pengaruh Gender Persepsi Sanksi Perpajakan Dan Program SAMSAT Corner Terhadap Kepatuhan Wajib Pajak Kendaraan Bermotor (Survei Pada Kantor Bersama SAMSAT Kota Yogyakarta). Universitas Muhammadiyah Yogyakarta.

Hillman, A. L. (2019). Public Finance and Public Policy: A Political-Economy Perspective on the Responsibilities and Limitations of Government, third ed. Cambridge University Press, Cambridge UK. https://doi.org/10.1017/978131647978o

Hsu, S.L., Walters, J., Purgas, A. (2008). Pollution tax Heuristics: an empirical study of willingness to pay higher gasoline taxes. Energy Pol. 36, 3612-3619.

Huddy, L. (2001). From social to political identity: a critical examination of social identity theory. Polit. Psychol. 22, 127-156. https://doi.org/10.1111/0162-895X.00230

Ibn Uthaimeen, M. (2020). The fatwa regarding payment of taxes using bank usury (n.d.), Available at https://binothaimeen.net/content/3031 (accessed 1July 2020).

Inglehart, R., Haerpfer, C., Moreno, A., Welzel, C., Kizilova, K., Diez-Medrano, J., Lagos, M., Norris, P., Ponarin, E., Puranen, B., et al., (2014). http://www.worldvaluessurvey.org/WVSDocumentationWV6.jsp

Israel, D.K. (2007). Charitable donations: evidence of demand for environmental protection? Int. Adv. Econ. Res. 13, 171-182.

Kakunsi, E. (2017). Pengaruh Gender dan tingkat pendidikan terhadap kepatuhan wajib pajak di wilayah Kantor Pelayanan Pajak Pratama Tahuna. Jurnal Riset Akuntansi Going Concern, 2, 12, Universitas Sam Ratulangi 391-40o. https://doi.org/10.32400/gc.12.2.17771.2017

Kleven, H. J., Knudsen, M. B., Kreiner, C. T., Pedersen, S., \& Saez, E. (2011). Unwilling or unable to cheat? Evidence from a tax audit experiment in Denmark. https://doi.org/10.3386/w15769

Luttmer, E. F. P., \& Singhal, M. (2014). Tax Morale. Journal of Economic Perspectives, 28(4), 149-168. https://doi.org/10.1257/jep.28.4.149

Nurunnabi, M. (2018). Accounting for accountability: A critical reflection on the private higher education in Bangladesh. Administration \& Society, 50(3),429-470.

Paetzold, J., Winner, H. (2016). Taking the high road? Compliance with commuter tax allowances and the role of evasion spillovers. J. Publ. Econ. 143, 1-14. https://doi.org/10.1016/j.jpubeco.2016.08.0o1

Pomeranz, D. (2015). No taxation without information: deterrence and self-enforcement in the value added tax. Am. Econ. Rev. 105 (8), 2539-2569. https://doi.org/10.1257/aer.20130393

Ridwan, S. (2017). Pengantar Statistika Untuk Penelitian. Bandung: Alfabeta.

Rincke, J., Traxler, C. (2011). Enforcement spillovers. Rev. Econ. Stat. 93 (4), 1224-1234. https://doi.org/10.1162/REST_a_oo128

Solomon, B.D., Johnson, N.H. (2009). Valuing climate protection through willingness to pay for biomass ethanol. Ecol. Econ. 68, 2137-2144.

Sugiono. (2016). Metode Penelitian Kuantitatif, Kualitatif Dan R Dan D. Bandung: Alfabeta. 
Tjongari, F. V. (2014). Analisis faktor-faktor individual yang berpengaruh terhadap pengambilan keputusan etis konsultan pajak (Survey pada konsultan pajak di Jawa Timur), Tax \& Accounting Review, 4, 2. https://doi.org/10.1886o/em.v4i2.2456

Torgler, B. (2002). Speaking to theorists and searching for facts. Tax morale and tax compliance in experiments. Journal of Economic Surveys, 16(5), 657-683. https://doi.org/10.1111/1467-6419.00185

Torgler, B. (2016). The Importance of Faith: Tax Morale and Religiosity, 61, Journal of Economic Behavior \&Organization, 81-109. https://doi.org/10.1016/j.jebo.2004.10.007

Torgler, B., García-Vali nas, M.A. (2007). The determinants of individuals' attitudes towards preventing environmental damage. Ecol. Econ. 63, 536-552.

Utama, A. (2016). Pengaruh Religiusitas Terhadap Perilaku Kepatuhan Wajib Pajak Orang Pribadi Di Provinsi DKI Jakarta, 2, 1-13.

Weber, M. (1930). The Protestant Ethic and the Spirit of Capitalism [1905]. Scribner's, New York, NY.

Williamson, V. S. (2017). Read My Lips: Why Americans Are Proud to Pay Taxes. Princeton University Press. https://doi.org/10.1515/9781400885015

Yitzhaki, S. (1974). A note on income tax evasion: a theoretical analysis. J. Publ. Econ. 3, $201-202$. https://doi.org/10.1016/o047-2727(74)90037-1 